DOI https://doi.org/10.30525/978-9934-26-007-0-16

\title{
ДОСВІД КРАЇН ЄВРОПЕЙСЬКОГО СОЮЗУ $З$ ПИТАНЬ ПРАВОВОГО РЕГУЛЮВАННЯ ПРАЦІ ПОСАДОВИХ ОСІБ ОРГАНІВ МІСЦЕВОГО САМОВРЯДУВАННЯ ТА ПЕРСПЕКТИВИ ЙОГО ВПРОВАДЖЕННЯ В УКРАЇНІ
}

\author{
Мельник П. В., Мельник В. П.
}

\section{ВСТУП}

Утвердження в Україні демократичної, соціальної та правової держави зумовлює об'єктивні та закономірні процеси пов'язані із системними соціально-економічними реформами та, зокрема, реформою децентралізації влади.

Відповідно до Плану заходів із реалізації нового етапу реформування місцевого самоврядування та територіальної організації влади в Україні на 2019-2021 роки, затвердженого розпорядженням Кабінету Міністрів України від 23 січня 2019 р. № 77-р, одним із ключових завдань реформи децентралізації є створення належної ресурсної бази для здійснення повноважень органів місцевого самоврядування ${ }^{1}$. 3 огляду на вищезазначене, особливо актуальним стає питання правового регулювання права на працю в умовах процесу децентралізації.

Крім того, внаслідок підписання Угоди про асоціацію між Україною, з однієї сторони, та Європейським Союзом, Свропейським співтовариством 3 атомної енергії та їхніми державами-членами, 3 іншої сторони (Угоду ратифіковано згідно із заявою Законом № 1678-VII від 16.09.2014р.) $)^{2}$, Україна також взяла на себе зобов'язання узгодити чинне законодавство про службу в органах місцевого самоврядування з європейськими стандартами, що зумовлює необхідність вивчення відповідного законодавства країн Свропейського Союзу.

Особлива актуальність досліджуваної тематики також зумовлена кодифікаційними процесами в галузі трудового права України та очікуваним прийняттям у найближчому часі Трудового кодексу України та нового закону про службу в органах місцевого самоврядування.

\footnotetext{
${ }^{1}$ План заходів з реалізації нового етапу реформування місцевого самоврядування та територіальної організації влади в Україні на 2019-2021 роки : Розпорядження Кабінету Міністрів України від 23 січня 2019 p. № 77-p. URL: https://zakon.rada.gov.ua/laws/show/77-2019-\%D1\%80?lang=en.

2 Угода про асоціацію між Україною, з однієї сторони, та Європейським Союзом, Європейським співтовариством 3 атомної енергії і їнніми державами-членами, з іншої сторони. Угоду ратифіковано із заявою Законом № 1678-VII від 16.09.2014 p. URL: http://zakon0.rada.gov.ua/laws/show/984_011/ paran147\#n147.
} 
Правове регулювання праці посадових осіб органів місцевого самоврядування було предметом досліджень таких вчених, як Л.Ю. Бугров, В.Я. Бурак, В.В. Жернаков, Н.Д. Гетьманцева, Г.С. Гончарова, О.В. Карпушкін, О.О. Конопельцева, Є.В. Краснов, П.Д. Пилипенко, В.І. Прокопенко, Г.І. Чанишева, В.І. Щербина, М.М. Якименко, О.М. Ярошенко та інших. Тим не менше комплексне дослідження цього питання в контексті досвіду країн Європейського Союзу відсутнє.

Мета цього дослідження полягає в тому, щоб на підставі аналізу досвіду країн Європейського Союзу (далі - ЄС) виявити стан і визначити закономірності, тенденції правового регулювання праці посадових осіб органів місцевого самоврядування в $\mathrm{CC}$, а також розробити обгрунтовані пропозиції щодо вдосконалення українського законодавства у цій сфері.

\section{1. Базові засади правового регулювання праці посадових осіб органів місцевого самоврядування в країнах $\mathbf{C C}$}

Інститут правового регулювання праці посадових осіб органів місцевого самоврядування в країнах СС характеризується специфічними рисами, які $€$ відмінними від українського досвіду правової регламентації зазначених правовідносин. Варто зауважити, що термін «посадова особа органу місцевого самоврядування» або «муніципальний службовець» у законодавстві більшості зарубіжних країн відсутній. Водночас у відповідних нормативно-правових актах містяться категорії «муніципальний радник», «мер», «службовець муніципальної ради» (Великобританія, Франція, США, Німеччина) $)^{3}$.

Базові засади правової регламентації праці в межах муніципальної служби в країнах $\mathrm{CC} \mathrm{закріплені} \mathrm{в} \mathrm{Європейській} \mathrm{Хартії} \mathrm{місцевого} \mathrm{самоврядування}$ від 15.10.1985 р. (далі - Свропейська Хартія) ${ }^{4}$.

Так, зокрема, у ст. 6 Європейської Хартії «Відповідність структур і адміністративних ресурсів задачам органів місцевого самоврядування» закріплено, що органи місцевого самоврядування в межах, встановлених законодавством, мають право самостійно встановлювати свої внутрішні організаційні структури і, відповідно, встановлюють організаційну основу муніципальної служби 5 . Відповідно до положень ст. 7 Європейської Хартії «Умови здійснення функцій на місцевому рівні», статус місцевих обраних представників передбачає не тільки вільне здійснення ними мандата, а й належну грошову компенсацію витрат у зв'язку зі здійсненням ними своїх

\footnotetext{
${ }^{3}$ Муниципальное право зарубежных стран (сравнительно-правовой анализ) : Учебное пособие для вузов / под ред. д.ю.н., профессора В.В. Еремяна. Москва : Академический проект; Фонд «Мир». 2005 г. С. 55.

${ }_{4}^{4}$ Свропейська соціальна хартія від 03.05.1996р., ратифікована Україною згідно із Законом від 14.09.2006 p. № 137-V. URL: http://zakon2.rada.gov.ua/laws/show/994_062.

5 там само.
} 
повноважень, а також, у разі потреби, грошову компенсацію за втрачений заробіток чи винагороду за виконану роботу. Виборним особам має бути гарантоване також відповідне соціальне забезпечення ${ }^{6}$.

Іншими словами, виконання громадських публічних обов'язків має відповідним чином компенсуватися. Однак положення Європейської Хартії визнаються не всіма країнами. Якщо Україна ратифікувала в цій частині Європейську Хартію без застережень, то Греція, Болгарія, Австрія, Латвія, Румунія і низка інших країн не вважають себе зв'язаними положеннями п. 2 ст. 7 Хартії про належну грошову компенсацію виборним особам) ${ }^{7}$.

Окремі аспекти правового регулювання праці посадових осіб місцевого самоврядування закріплені в Гельсінській декларації регіонального самоврядування, прийнятій на Конференції міністрів держав - членів Ради Свропи, відповідальних за місцеве та регіональне врядування 28 червня 2002 року (далі - Гельсінська декларація) ${ }^{8}$. Так, відповідно до п. 10.3 Додатку «Основні поняття і загальні принципи регіонального самоврядування, визначені CDLR» до Гельсінської декларації, умови служби працівників органів регіональної влади мають відповідати загальним принципам державної служби та бути такими, щоб забезпечувати підбір висококваліфікованих працівників на основі особистих якостей i компетентності; 3 цією метою варто забезпечувати адекватні можливості для навчання, винагороди та кар'єрного росту'.

Таким чином, у Гельсінській декларації закріплено підхід, відповідно до якого загалом правовий статус муніципальних службовців (зокрема, в частині їх добору, оплати та режиму праці) має відповідати статусу державного службовця (хоча Гельсінська декларація при цьому не вимагає впровадження ідентичного правового статусу щодо зазначених категорій публічних службовців).

Схоже положення міститься і в Рекомендації Комітету Міністрів Ради Свропи REC(2007)12 про розвиток потенціалу на місцевому та регіональному рівні, прийнятій 10 жовтня 2007 року на 1006-му засіданні заступників міністрів, в п. 4 якої рекомендовано державам-членам Ради Європи переглянути, коли це в межах їхньої компетенції, разом із відповідними зацікавленими сторонами, включаючи, залежно від обставин, місцеві органи влади та/або їх асоціації, умови служби працівників органів місцевого врядування з огляду на забезпечення того, щоб вони дозволяли

\footnotetext{
6 Свропейська соціальна хартія від 03.05 .1996 р., ратифікована Україною згідно із Законом від 14.09.2006 p. № 137-V. URL: http://zakon2.rada.gov.ua/laws/show/994_062.

7 Там само.

${ }^{8}$ Гельсінська декларація регіонального самоврядування, прийнята на Конференції міністрів держав членів Ради Свропи, відповідальних за місцеве та регіональне врядування 28 червня 2002 року. URL: https://rm.coe.int/16805e1fde.

9 Там само.
} 
брати на роботу висококваліфікований штатний персонал на основі досвіду та кваліфікації, та щоб із цією метою забезпечувалися належні можливості для навчання, оплати праці та кар'єрного росту ${ }^{10}$.

В іншій Рекомендації Комітету Міністрів Ради Свропи REC(2001)19 про участь громадян у місцевому суспільному житті, прийнятій 6 грудня 2001 року на 776-му засіданні заступників міністрів встановлено, що одним iз заходів, спрямованих на заохочення та підтримку участі громадян у місцевому суспільному житті, $є$ заохочення представників влади, обраних на місцевому рівні, і працівників органів місцевої влади всіма придатними засобами, зокрема розробленням кодексів поведінки, поводитися згідно з високими етичними стандартами й забезпечувати їх дотримання (п. 4 Додатку II «Кроки й заходи, спрямовані на заохочення та підтримку участі громадян у місцевому суспільному житті») ${ }^{11}$.

Таким чином, на базовому (рамковому) рівні Європейська хартія та численні рекомендації Ради Європи не встановлюють докладного правового регулювання праці посадових осіб органів місцевого самоврядування, проте визначають загальні напрями такого регулювання: 1) держави-члени Ради Європи мають забезпечити муніципальним службовцям умови праці, еквівалентні державним службовцям; 2) муніципальним службовцям мають забезпечуватися належні можливості для навчання, оплати праці та кар'єрного росту; 3) мають бути розроблені кодекси поведінки муніципальних службовців із метою заохочення та підтримки участі громадян у місцевому суспільному житті.

Далі в межах цього дослідження буде проаналізовано досвід окремих країн ЄС у сфері правового регулювання праці посадових осіб органів місцевого самоврядування.

\section{2. Правове регулювання праці посадових осіб органів місцевого самоврядування в окремих країнах СС}

Першою європейською країною, де зародився інститут служби в органах місцевого самоврядування, є Німеччина. Правовою основою формування місцевого самоврядування в Німеччині $є$ Прусський Статут міст, введений фон Штейном в 1808 p. Він закріплював розвиток системи місцевого

\footnotetext{
${ }^{10}$ Рекомендація Комітету Міністрів Ради Свропи REC(2007)12 про розвиток потенціалу на місцевому та регіональному рівні, прийнята 10 жовтня 2007 року. URL: https:/www.coe.int/en/web/freedom-expression/ committee-of-ministers-adopted-texts/-/asset_publisher/aDXmrol0vvsU/content/recommendation-cm-rec-2007-2of-the-committee-of-ministers-to-member-states-on-media-pluralism-and-diversity-of-mediacontent?_101_INSTANCE_aDXmrol0vvsU_viewMode=view/

11 Рекомендація Комітету Міністрів Ради Європи REC(2001)19 про участь громадян у місцевому суспільному житті, прийнята 6 грудня 2001 року. URL: https:/www.coe.int/en/web/good-governance/ newsroom/-/asset_publisher/HvcSRSRYLNU4/content/participation-of-citizens-in-local-public-life-revision-ofrecommendation-cm-rec-2001-19-of-the-committee-of-ministers?inheritRedirect=false.
} 
самоврядування: поряд із представницьким міським органом утворювався колегіальний виконавчий орган - магістрат ${ }^{12}$.

Правовий статус муніципальних службовців визначається в Німеччині федеральними і земельними законами, що встановлюють посадовий оклад. Питання зайнятості робітників і службовців регулюються федеральними тарифними угодами. Комуни, як члени місцевих спілок роботодавців, зобов’язані дотримуватися цих угод ${ }^{13}$.

Основний Закон Федеральної Республіки Німеччини містить принципове положення (ст. 33, абз. 4) про організацію служби, відповідно до якого здійснення владних повноважень має здійснюватися на постійній основі. 3 цього випливає, що, як правило, здійснення публічно-владних повноважень має доручатися офіційним посадовим особам, які перебувають на службі в публічно-правовій корпорації. На федеральному рівні в Німеччині прийняті закони: «Федеральний закон про оклади», «Федеральні основи законодавства про муніципальних чиновників» та інші. На рівні земель існують нормативні положення про просування по муніципальній службі. У муніципальних утвореннях основним органом, що встановлює правила для муніципальних чиновників, є представницький орган німецької громади ${ }^{14}$.

На муніципальній службі в органах місцевого самоврядування Німеччини перебувають виборні чиновники і чиновники, що надійшли на службу за контрактом. Причому виборні чиновники можуть бути штатними професійними чиновниками, які працюють певний термін, або поза штатними, що залежить від типу організації громади. Так, наприклад, виборний бургомістр може бути як штатним працівником, так i позаштатним співробітником. Позаштатних чиновників так само називають почесними. Почесні чиновники поряд із виконанням своїх публічно-правових обов'язків відповідно до позаштатної посади можуть займатися в повному обсязі іншою діяльністю. Виборні чиновники, включені в штат на час виконання своїх повноважень, як і чиновники, прийняті на службу за контрактом, не можуть займатися іншою діяльністю. У цьому випадку почесні чиновники можуть отримувати грошову компенсацію у вигляді «почесного окладу». Між штатними і почесними чиновниками існують так само відмінності в пенсійному забезпеченні. Чиновник, тимчасово включений у штат, отримує державну пенсію, як і чиновник, прийнятий на довічну службу ${ }^{15}$.

\footnotetext{
${ }^{12}$ Красівський О.Я. Еволюція системи місцевого самоврядування у Німеччині (на прикладі землі Бранденбург): історико-управлінський аспект / О.Я. Красівський, М.М. Янишевський. Аспекти публічного управління. 2016. № 6/7 (32/33). С. 86.

${ }^{13}$ Вольман Хельмут. Сравнительный анализ систем местного самоуправления в Германии и в европейских странах. Мунищипальная власть. 2015. № 1-2. С. 63.

14 Там само, с. 64.

15 Муниципальное право зарубежных стран (сравнительно-правовой анализ) : Учебное пособие для вузов / под ред. д.ю.н., профессора В.В. Еремяна. Москва : Академический проект; Фонд «Мир». 2005 г. С. 116.
} 
У Німеччині особи, які обіймають виборні посади, здійснюють громадські обов'язки, що розуміється не як безоплатна діяльність, а як діяльність, здійснювана поряд 3 основною роботою, службою на постійній основі, спрямованою на задоволення суто особистих, індивідуальних потреб і інтересів конкретних осіб. Громадянин може відмовитися від виборної посади в зумовлених випадках: у зв'язку з досягненням віку, деяких професійних, сімейних обставин, стану здоров'я. Крім грошової винагороди, відповідно до статуту громадяни, що обіймають почесну посаду, отримують компенсацію за виконання своїх обов'язків, - участь у засіданнях, нарадах та інших заходах. Їм компенсується: понесена і документально підтверджена втрата в заробітку, втрата часу відповідно до встановленої ставки тощо. Така норма міститься і в параграфі 19 «Винагорода за виконання роботи на громадських засадах» «Положення про громади землі Баден-Вюртемберг» ${ }^{16}$.

Органи місцевого самоврядування мають право приймати на службу чиновників, службовців і робітників для виконання відповідних повноважень, підвищувати їх на посаді і звільняти. Прийом співробітників здійснюється в рамках штатного розкладу (додаток до бюджетного плану) i тому перебуває в компетенції органу представницької влади комуни. Органи місцевого самоврядування, як правило, самостійно навчають чиновників і службовців. Навчання відбувається в спеціальних навчальних закладах і під час практичної роботи. Кадрова політика набуває на сучасному етапі пріоритетне значення для місцевого самоврядування: у великих містах у комунальній адміністрації працюють представники більш ніж ста професій ${ }^{17}$.

Таким чином, нині в Німеччині правове регулювання праці муніципальних службовців здійснюється на двох рівнях: федеральному та в межах окремих земель. Досить цікавим із точки зору запозичення видається досвід Німеччини щодо поділу службовців на штатних і почесних чиновників із чітким розмежуванням їхнім функціональних повноважень та режиму й оплати праці.

Цікавим є досвід Великобританії у сфері регулювання праці муніципальних службовців. Базовим у цій сфері $є$ Закон про децентралізацію від 15 листопада 2011 р., який встановлює функції і процедури функціонування місцевих та деяких інших органів влади ${ }^{18}$ (далі - Закон про децентралізацію).

Насамперед необхідно зазначити, що в цій країні була скасована посада мера як незалежної посадової особи. Представницькі функції здійснює голова муніципальної ради, він же організовує роботу представницького

\footnotetext{
16 Люхтерхандт Г. Местное самоуправление в новых землях Германии. Берлин, 2012 г. С. 67.

${ }^{17}$ Там само. С. 68.

18 Досвід децентралізації у країнах Європи : збірник док. пер. $з$ іноз. мов / Заг. ред. В.Б. Гройсмана. Київ : Інститут законодавства Верховної Ради України, 2015. С. 329-358.
} 
органу, його постійних комісій, інших форм діяльності муніципальних радників, підтримує зв'язок із громадськістю, контролює за допомогою постійних комісій діяльність виконавчого органу, підтримує зв'язок із главою муніципального управління та його командою. Всі вони, в тому числі і глава виконавчої влади, є найманими працівниками муніципальної ради, утворюють штат муніципальної служби ${ }^{19}$.

Правове регулювання статусу муніципальних службовців здійснюється спільно муніципалітетами та органами вищої ланки управління. Формування кадрів апарату місцевого управління, регулювання правового становища муніципальних чиновників охоплюється поняттям «муніципальна служба». Чиновники, що працюють в апараті місцевого органу, не $\epsilon$ державними службовцями, а службовцями ради, яка їх призначила. У радах створюються спеціальні комітети з питань кадрів, які розробляють схеми класифікації службовців, схеми посадових окладів, правила відбору кандидатур, розглядають трудові конфлікти тощо ${ }^{20}$.

Як правило, орган місцевого управління має право призначати таких чиновників, яких він вважає за необхідне. Однак законодавством може встановлюватися перелік чиновників, які в обов'язковому порядку мають бути призначені: наприклад, чиновник із питань освіти, інспектор-фахівець в області мір i вагів та ін. Муніципальні службовці працюють на контрактній основі. Умови праці та оплата праці встановлюються Національною об'єднаною радою та іншими подібними до неї органами, до складу яких входять представники органів місцевого управління $\mathrm{i}$ чиновники. Муніципалітети мають право, але не зобов'язані приймати до виконання рекомендації цих органів ${ }^{21}$.

Серед категорій муніципальних службовців варто виокремити головного адміністратора. Важливість цієї фігури в апараті місцевої ради пояснюється тим, що практично всі питання місцевого життя попередньо або остаточно вирішуються в комітетах, в діяльності яких беруть активну участь чиновники, що займаються розробкою спільної політики. Множинність комітетів ради і різних відділів поряд із відсутністю одноосібного або колегіального глави виконавчого апарату надають особливу важливість координації роботи всіх структурних підрозділів місцевого органу. Цю функцію (поряд 3 іншими) і здійснює головний адміністратор, фактично виступаючи як глава апарату чиновників ${ }^{22}$.

\footnotetext{
19 Лапшина И.Е. Местное управление и территориальная организация публичной власти в Великобритании. Правовая политика и правовая жизнь. 2012. № 2. С. 142.

${ }^{20}$ Там само.

21 Лапшина И.Е. Формы взаимодействия центральных и местных органов управления Великобритании. Государство и право. 2013. № 5. С. 78.

${ }^{22}$ Там само. С. 79.
} 
Окремо варто підкреслити положення ст.ст. 28, 29 Закону про децентралізацію, якими встановлено: «<..> відповідний орган влади має забезпечити, аби будь-який кодекс, ухвалений ним згідно зі статтею 27(2) (кодекс поведінки), загалом відповідав таким принципам - (a) безкорисливість; (b) цілісність; (c) об’єктивність; (d) відповідальність; (е) відкритість; (f) чесність; (g) уміння повести за собою (керівництво). <...> Інспектор відповідного органу влади має створити та вести реєстр інтересів членів та кооптованих членів відповідного органу влади. (2) Згідно з положеннями цієї Глави, відповідний орган влади визначає, що саме має вноситися до зазначеного реєстру» ${ }^{23}$.

На нашу думку, британський досвід щодо створення та ведення реєстру інтересів членів та кооптованих членів органу місцевого самоврядування має бути впроваджений і в українському законодавстві, адже, по суті, нині питання конфлікту інтересів дістало лише фрагментарне закріплення як в антикорупційному законодавстві, так і законодавстві про публічну службу.

У Франції правовий статус посадових осіб органів місцевого самоврядування визначений Законом від 13 липня 1983 року (Закон оперує поняттям «муніципальний службовець») та він $є$ ідентичним статусу державних службовців, тобто за чиновниками місцевої публічної служби закріплені ті ж права і обов'язки, що і за чиновниками державної служби. Разом із тим деякі категорії публічних службовців (військовослужбовці, поліцейські, працівники судів, службовці парламенту і низка інших посадових осіб публічних органів) не підпадають під дію цього закону, їх служба регулюється особливими нормативно-правовими актами, вони додатково обмежені в своїх правах, наприклад, не мають права на страйк тощо ${ }^{24}$.

У Франції не можуть отримати статусу муніципального службовця особи, які не мають французького громадянства, позбавлені громадянських прав, які мають судимість, яка виключає обійняття посади в публічній службі, що не відповідають вимогам до фізичного стану i вимогам Кодексу національної служби, тобто які порушили закон про військову повинність, що не мають необхідної освіти i кваліфікації (для деяких категорій службовців), що перевищили максимальний віковий ценз (для більшості посад вік становить 40-45 років $)^{25}$.

\footnotetext{
23 Досвід децентралізації у країнах Європи : збірник док. пер. з іноз. мов / Заг. ред. В.Б. Гройсмана. Київ : Інститут законодавства Верховної Ради України, 2015. С. 336-337.

${ }^{24}$ Янгол Н. Г., Болотина Елена Валентиновна Правовой статус муниципальных служащих во Франции. Вестник Санкт-Петербургского университета МВД России. 2016. № 1. URL: https://cyberleninka.ru/ article/n/pravovoy-status-munitsipalnyh-sluzhaschih-vo-frantsii.

25 Там само.
} 
Французьке законодавство про муніципальну службу гарантує чиновникам свободу думки (свободу вираження поглядів). Закон забороняє проводити будь-яку різницю між службовцями 3 огляду на їхні політичні, профспілкові, філософські і релігійні погляди, стать або етнічну приналежність. Однак, як виняток, може передбачатися роздільний набір на службу чоловіків або жінок, коли приналежність до одного чи іншого підрозділу муніципальної служби $є$ визначальною умовою виконання службових обов'язків, тобто перевагу під час прийому на службу чоловікам чи жінкам може бути зроблено тільки через специфіку служби. У процесі балотування на виборну посаду або обрання службовця в орган місцевого самоврядування на просування по службі не можуть впливати результати голосування або думки, висловлені зацікавленими особами під час їх виборчої кампанії або в період дії депутатського мандата ${ }^{26}$.

Дохід сучасних французьких муніципальних службовців складається 3 трьох частин: основної заробітної плати, додаткової винагороди і соціальних пільг. Найбільш важливою з них $є$ заробітна плата. У разі страйку заробітна плата не виплачується. Розмір заробітної плати службовців регулюється тарифною сіткою, введеною ще в 1946-1947 pp. Вона створила цілісну систему посадових окладів, підвищення яких проводиться для всіх категорій службовців одночасно. Це веде і до автоматичного підвищення їх пенсій. На службовців поширюються спеціальні режими соціального страхування і пенсійного забезпечення ${ }^{27}$.

Чиновники мають право на щорічні відпустки (зазвичай ця відпустка дорівнює п'яти тижням), відпустки через хворобу (загальна тривалість може досягати дванадцяти місяців поспіль зі збереженням платні в повному обсязі протягом перших трьох місяців і виплатою 50\% платні протягом наступних дев'яти місяців; також зберігається право на повну суму сімейної доплати і допомогу на житло), відпустки по материнству і відпустки, пов'язані з виконанням батьківських обов'язків (до досягнення дитиною 3-річного віку), відпустки на професійну і профспілкову підготовку (зі збереженням платні максимальною тривалістю 12 робочих днів на рік) ${ }^{28}$.

У Законі 1983 р. не міститься визначення дисциплінарного проступку муніципального службовця. Дисциплінарними проступками вважаються, наприклад, непокора волі начальника, недотримання службової таємниці, невиконання службових обов'язків і навіть поведінка в приватному житті, несумісна зі здійсненням публічної служби. Дисциплінарні стягнення, які накладаються на службовців, діляться на чотири групи: 1) попередження,

\footnotetext{
${ }^{26}$ Миронов Н. Местное самоуправление во Франции. Муниципальная власть. 2014. № 2. С. 46.

${ }^{27}$ Там само.

${ }^{28}$ Там само. С. 47.
} 
догана, тимчасове відсторонення від посади на строк до 3 днів; 2) зниження в ранзі, тимчасове відсторонення від посади на термін від 4 днів до двох тижнів; 3) пониження в посаді; тимчасове відсторонення від посади на термін від 16 днів до 16 місяців; 4) переведення на пенсію в офіційному порядку, звільнення ${ }^{29}$.

Згідно зі ст. 89 Закону від 26 січня 1984 р. зі стягнень першої групи тільки догана i тимчасове відсторонення від виконання службових обов'язків заносяться до особової справи службовця. Вони автоматично виключаються 3 неї через три роки, якщо протягом цього терміна не було винесено жодного нового дисциплінарного стягнення ${ }^{30}$.

Таким чином, у Франції досить детально врегульовано питання соціального забезпечення та дисциплінарної відповідальності муніципальних службовців, в той час як Закон України «Про службу в органах місцевого самоврядування» із цього приводу містить лише три статті, більшість положень яких вже виключені. 3 огляду на це відповідний французький досвід має бути перенесений і в українське законодавство.

Вартою уваги також є законодавча база організації праці службовців місцевого самоврядування у Польщі. Так, базові засади організації роботи службовців місцевого самоврядування у Польщі визначені у Законі «Про працівників самоврядування», прийнятому Сеймом у 2008 p. $^{31}$ (далі-Закон).

Відповідно до цього Закону добір на службу в місцеве самоврядування у Польщі здійснюється трьома способами: обрання, призначення та укладання трудового договору. Шляхом обрання заступають на посади на рівні гміни - війт (бургомістр та президент міста), шляхом призначення заступник війта (бургомістра чи президента), скарбник гміни, шляхом укладання трудового договору - інші службовці місцевого самоврядування. Кількість радників та консультантів не може перевищувати 3 осіб у гмінах чисельністю до 20 тис. осіб, 5 осіб - у гмінах із чисельністю до 100 осіб, 7 осіб - в інших гмінах ${ }^{32}$.

Ст. 6 Закону визначено вимоги до працівника органу місцевого самоврядування. Так, працівником самоврядування може бути особа, яка: 1) є громадянином Польщі; 2) має повну здатність до юридичних дій, а також користується всіма публічними правами; 3) має професійну

\footnotetext{
${ }^{29}$ Янгол Н.Г., Болотина Елена Валентиновна Правовой статус муниципальных служащих во Франции. Вестник Санкт-Петербургского университета МВД России. 2016. № 1. URL: https://cyberleninka.ru/article/ $\mathrm{n}$ /pravovoy-status-munitsipalnyh-sluzhaschih-vo-frantsii.

${ }^{30}$ Taм само.

${ }^{31}$ Ustawa z dnia 21 listopada 2008 r. o pracownikach samorządowych. URL: https://isap.sejm.gov.pl/ isap.nsf/DocDetails.xsp?id=WDU20082231458.

32 Там само.
} 
кваліфікацію, необхідну до виконання роботи на визначеній посаді. Працівником самоврядування, працевлаштованим на підставі обрання (виборів) або призначення, може бути особа, яка відповідає вищезазначеним вимогам, а також не була засуджена правомочним вироком суду за умисний злочин, переслідуваний із публічного звинувачення або за умисний казначейський злочин. Своєю чергою, працівником самоврядування, працевлаштованим на підставі трудового договору на посаді службовця, може бути особа, яка відповідає вищезазначеним вимогам, а також додатково: 1) має щонайменше середню або середню спеціальну освіту; 2) не була засуджена правомочним вироком суду за умисний злочин із публічного обвинувачення або за умисний казначейський злочин; 3) має бездоганну репутацію. Працівником самоврядування, працевлаштованим на підставі трудового договору на керівній посаді службовця, може бути особа, яка виконує вимоги, визначені в вище, а також додатково: 1) має щонайменше трирічний стаж роботи або виконувала протягом щонайменше 3 років господарську (економічну) діяльність, характерну (сумісну) із вимогами цієї посади; 2) має вищу освіту в розумінні положень про вищу школу і науку ${ }^{33}$.

Варто зазначити, що вимога щодо бездоганної репутації є однією 3 умов sine qua non (те, без чого неможливо) працевлаштування (зайнятості) працівників самоврядування. Взірцем особи, що підпадає під це визначення, $€$ особа, що характеризується етичністю, чесністю, ретельністю, відповідальністю, лояльністю чи вмінням надавати перевагу публічним справам над приватними. На практиці, одним із критеріїв оцінки, чи кандидат володіє бездоганною репутацією, може бути довідка про несудимість.

Ст. ст. 8-10 Закону визначено сторону роботодавця у правовідносинах із муніципальними службовцями. Так, роботодавцем війта $\epsilon$ управління гміни, а дії правового характеру з питань трудового права щодо війта (бургомістра, президента міста), пов'язані з укладанням і розірванням трудових відносин, виконує голова ради гміни, а інші дії - визначена через війта (бурмістра, президента міста) особа, заступник або секретар гміни, при цьому заробітну плату війта встановлює рада гміни, в порядку ухвали ${ }^{34}$.

Своєю чергою, роботодавцем старости, віцестарости і членів правління повіту $є$ повітове староство, а дії правового характеру 3 питань трудового права щодо старости, пов'язані із укладанням і розірванням трудових відносин виконує глава ради повіту, а інші дії - визначена через старосту особа заступник або секретар повіту, при цьому заробітну плату

\footnotetext{
${ }^{33}$ Ustawa z dnia 21 listopada 2008 r. o pracownikach samorządowych. URL: https://isap.sejm.gov.pl/ isap.nsf/DocDetails.xsp?id=WDU20082231458.

${ }^{34}$ Там само.
} 
старости установлює рада повіту, в порядку ухвали. Дії правового характеру з питань трудового права щодо інших членів правління повіту виконує староста повіту ${ }^{35}$.

Роботодавцем маршалка, віцемаршалка і членів правління воєводства $\epsilon$ маршальське управління. Дії правового характеру з питань трудового права щодо маршалка воєводства, пов'язані з укладанням і розірванням трудових відносин виконує глава сеймику воєводства, а іншу діяльність - визначена через маршала підмінна особа або секретар воєводства. Діяльність у справах з області трудового права щодо інших членів правління воєводства виконує маршалек воєводства ${ }^{36}$.

Питанням виникнення та зміни службово-трудових відносин присвячений розділ II Закону. Зокрема, ст. 11 Закону встановлено, що набір кандидатів на вільні посади службовців (управлінців), у тому числі на керівні посади службовців, відкритий i конкурентоспроможний. Вакантною посадою службовця (управлінця), а також вільною керівною посадою службовця, $\epsilon$ посада, на яку, згідно з положеннями закону або в порядку домовленості, не був переведений працівник самоврядування, працевлаштований на посаді службовця в цій або іншій установі, що володіє кваліфікаціями, необхідними на цій посаді або на цю посаду не був проведений набір або на яку, незважаючи на проведений набір, працівник не був працевлаштований ${ }^{37}$.

Оголошення про вакантну посаду службовця, а також керівну посаду службовця, про набір кандидатів на цю посаду розміщується у Бюлетені Публічної Інформації, і ст. 13 Закону містить детальне регулювання вимог до такого оголошення. Після проведення конкурсу невідкладно публікується інформація про результат конкурсу через повідомлення на інформаційній дошці в одиниці (установі), в якій був проведений конкурс, а також здійснюється публікація в Бюлетені не пізніше ніж через 3 місяці ${ }^{38}$.

Трудові відносини працівника самоврядування, працевлаштованого (зайнятого) на підставі трудового договору, укладаються безстроково або на визначений строк. Якщо $\epsilon$ необхідність заміщення працівника під час його виправданої відсутності на роботі, роботодавець може 3 цією метою залучити до роботи іншого працівника на підставі строкового трудового договору, що охоплює час такої відсутності ${ }^{39}$.

\footnotetext{
35 Ustawa z dnia 21 listopada 2008 r. o pracownikach samorządowych. URL: https://isap.sejm.gov.pl/ isap.nsf/DocDetails.xsp?id=WDU20082231458

36 Там само.

37 Там само.

38 Там само.

39 Там само.
} 
Для окремих категорій працівників Законом встановлено обов'язок проходження так званої «підготовчої служби», яка має на меті теоретичну i практичну підготовку працівника до належного виконання службових обов'язків. Підготовча служба триває не довше ніж 3 місяці і закінчується іспитом.

Значний інтерес становить аналіз правового врегулювання обов'язків посадових осіб органів місцевого самоврядування. У Законі цьому присвячений окремий розділ «Обов’язки працівників самоврядування», який регламентує досить широку сферу. У ст. 24 Закону передусім визначаються основні обов'язки працівників місцевого самоврядування, до яких зараховано виконання публічних завдань та контроль за публічними коштами, 3 урахуванням публічного та індивідуальних інтересів громадян. Іншими обов'язками працівників самоврядування є: дотримання Конституції Польщі та інших законодавчих актів; сумлінне, ефективне та неупереджене виконання завдань; надання інформації органам, інституціям і фізичним особам, а також документів, які знаходяться в одиниці самоврядування, якщо це не заборонено законом; збереження службової таємниці; ввічлива та доброзичлива поведінка у відносинах із громадянами, начальством, підлеглими та колегами; збереження гідності на робочому місці і за його межами; постійне підвищення професійної кваліфікації та умінь ${ }^{40}$.

У Законі закріплюється положення, що до обов'язків працівника самоврядування належить також сумлінне й ретельне виконання доручень начальства. Проте, якщо він переконаний, що доручення не відповідає закону або помилкове, він зобов'язаний повідомити в письмовій формі свого безпосереднього керівника. У разі письмового підтвердження доручення працівник зобов'язаний його виконувати, повідомивши водночас керівника установи, в якій він працює. Працівник не виконує доручення, якщо впевнений, що його виконання призведе до вчинення злочину, порушення або загрожує непоправними втратами, і негайно інформує про це керівника установи, в якій працює ${ }^{41}$.

Значна увага в розділі приділяється питанням оцінювання працівників самоврядування, прийнятих на посаду службовця, у тому числі на керівні посади. У ст. 27 визначається порядок ऑiі проведення. Оцінювання проводиться в письмовій формі безпосереднім керівником не рідше ніж один раз на 2 роки і не частіше ніж один раз на 6 місяців. Оцінка стосується виконання працівником обов'язків відповідно до обійманої посади. Безпосередній керівник вручає оцінку працівнику і керівнику установи.

\footnotetext{
${ }^{40}$ Ustawa z dnia 21 listopada 2008 r. o pracownikach samorządowych. URL: https://isap.sejm.gov.pl/ isap.nsf/DocDetails.xsp?id=WDU20082231458.

${ }^{41}$ Там само.
} 
Службовець може оскаржити оцінку в керівника установи протягом 7 днів із часу отримання оцінки, це оскарження має бути розглянуто протягом 14 днів. У разі відміни результату оцінку можна змінити або провести повторне оцінювання. У разі негативної оцінки нове оцінювання працівника самоврядування проводиться не раніше, ніж через 3 місяці. Отримання негативної оцінки вдруге тягне за собою розірвання трудового договору за умови дотримання термінів повідомлення. Керівник одиниці самоврядування має окреслити в розпорядженні спосіб проведення періодичної оцінки, період, за який вона проводиться, критерії, на підставі яких проводиться оцінка, а також шкалу оцінки, беручи до уваги необхідність правильного проведення оцінки та специфіку функціонування одиниці ${ }^{42}$.

Значна увага в законі приділена врегулюванню проблеми обмежень, пов'язаних із прийняттям на службу в органи місцевого самоврядування та проходженням служби. Так, ст. 26 забороняє відносини безпосередньої службової підпорядкованості між подружжям та особами, які знаходяться у стосунках кровного споріднення до другого ступеня або ознак першого ступеня чи у стосунках всиновлення, опіки чи піклування. У ст. 30 визначено, що працівник самоврядування, прийнятий на посаду службовця, у тому числі на керівну посаду, не може займатися іншими видами діяльності, пов'язаними із заняттями, що входять у коло службових обов'язків, викликаючи тим самим обгрунтовані підозри в упередженості або особистому інтересі. У разі підтвердження порушення будь-якої із заборон працівником трудові відносини розриваються без попереднього повідомлення або він відкликається з обійманої посади ${ }^{43}$.

Таким чином, варто констатувати розвиненість польського законодавства в частині правового регулювання праці посадових осіб місцевого самоврядування. У контексті України було б доцільно запозичити положення: 1) щодо процедури оголошення та проведення конкурсу на обійняття відповідних посад (зокрема, в частині прозорості та публічності оголошення про проведення конкурсу); 2) щодо підготовчої служби (деяким аналогом якого виступає інститут випробувального строку); 3) щодо обмежень, пов'язаних із прийняттям на службу в органи місцевого самоврядування та проходженням служби (особливо в частині конфлікту інтересів та наявності в працівника особистого інтересу); 4) щодо проведення періодичної оцінки (атестації).

$\mathrm{y}$ межах цього дослідження хотілося б також зупинитися на досвіді скандинавських країн щодо правового регулювання праці в муніципальній службі, зокрема, в частині забезпечення гендерної рівності працівників.

\footnotetext{
${ }^{42}$ Ustawa z dnia 21 listopada 2008 r. o pracownikach samorządowych. URL: https://isap.sejm.gov.pl/isap. nsf/DocDetails.xsp?id=WDU20082231458.

${ }^{43}$ Там само.
} 
31995 р. Закон про рівність жінок і чоловіків Фінляндії передбачає квоти забезпечення гендерної рівності, що стосуються правлінь муніципалітетів, комітетів та органів міжмуніципального співробітництва. Частка жінок i чоловіків у цих органах має бути не меншою від 40\%. Натомість ці положення не стосуються виборних рад. У 2012 р. на муніципальних виборах частка жінок-кандидатів становила $38,8 \%$, а частка обраних жінокчленів рад - 36,2\% ${ }^{44}$.

На нашу думку, аналогічне положення доцільно було б ввести і в українське законодавство, що б забезпечило більш справедливе представництво чоловіків та жінок на службі в органах місцевого самоврядування.

\section{3. Правове регулювання праці посадових осіб органів місцевого самоврядування в Угоді про асоціацію з СС}

Окремо в межах аналізу законодавства $€ C$ в частині правового регулювання муніципальної служби хотілося б зупинитися на Угоді про асоціацію між Україною, 3 однієї сторони, та Європейським Союзом, Європейським співтовариством 3 атомної енергії і їхніми державамичленами, з іншої сторони (Угоду ратифіковано згідно із заявою Законом № 1678-VII від 16.09.2014 р.) (далі - Угода про асоціацію) ${ }^{45}$.

Зокрема, відповідно до ст. 420 Угоди про асоціацію, співробітництво у галузях зайнятості, соціальної політики та рівних можливостей, передбачає досягнення таких цілей: a) покращення якості людського життя; b) протистояння спільним викликам, зокрема глобалізації та демографічним змінам; c) збільшення кількості та покращення якості робочих місць із гідними умовами праці; d) сприяння розвитку соціальної та юридичної справедливості в контексті реформуванні ринку праці; е) сприяння створенню на ринку праці таких умов, які б поєднували гнучкість та захищеність; f) сприяння впровадженню активних заходів на ринку праці та підвищення ефективності служб зайнятості з метою задоволення потреб на ринку праці; g) стимулювання розвитку ринків праці, що сприяють залученню малозабезпечених осіб; h) зменшення обсягів неформальної економіки шляхом трансформації нелегальної зайнятості; і) покращення рівня забезпечення охорони здоров'я та безпечних умов праці, зокрема шляхом проведення навчання і тренінгів із питань охорони здоров'я та безпеки праці, сприяння реалізації превентивних заходів, попередження ризиків великих аварій та управління токсичними хімічними речовинами, а також обмін доброю практикою та результатами

\footnotetext{
44 Місцеве самоврядування в країнах Скандинавії та Балтії. URL: http://old.decentralization.gov.ua/ pics/attachments/Misceve-samovryaduvannya-v-krayinah-Skandiinaviyi-ta-Baltiyi.pdf.

45 Угода про асоціацію між Україною, 3 однієї сторони, та Європейським Союзом, Свропейським співтовариством з атомної енергії і їхніми державами-членами, з іншої сторони. Угоду ратифіковано із заявою Законом № 1678-VII від 16.09.2014. URL: http://zakon0.rada.gov.ua/laws/show/984_011/paran147\#n147.
} 
досліджень у цій сфері; j) посилення рівня соціального захисту та модернізації систем соціального захисту, зокрема щодо якості, доступності та фінансової стабільності; k) скорочення бідності та посилення соціальної єдності; 1) забезпечення гендерної рівності та рівних можливостей для чоловіків та жінок у сфері зайнятості, освіти та навчання, економічної та суспільної діяльності, а також у процесі прийняття рішень; m) подолання дискримінації в усіх iï формах та проявах; n) посилення можливостей соціальних партнерів та сприяння соціальному діалогу ${ }^{46}$.

У контексті адаптації українського законодавства у вищезазначеній сфері до європейських вимог йдеться про такі нормативно-правові акти в межах $\mathrm{CC}$ :

- Директива Ради № 91/533/СЕС від 14.10 .1991 р. про обов'язок роботодавця інформувати працівників про умови, що застосовуються до контракту чи трудової угоди. Графік: Положення Директиви мають бути впроваджені протягом 4 років із дати набрання чинності цією Угодою;

- Директива Ради 1999/70/СС від 28.06 .1999 р. про рамкову угоду про роботу на визначений термін, укладену ЄКПС [Європейська конфедерація профспілок], СКПРЕ [Спілка конфедерацій підприємців і роботодавців Європи] та ЄЦРП [Свропейський центр роботодавців і підприємств]. Графік: положення Директиви мають бути впроваджені протягом 4 років із дати набрання чинності цією Угодою;

- Директива Ради № 97/81/СС від 15.12 .1997 р. про рамкову угоду про неповну зайнятість, укладену СКПРС [Спілка конфедерацій підприємців і роботодавців Європи], ЄЦРП [Європейський центр роботодавців і підприємств] та ЄКПС [Європейська конфедерація профспілок] - Додаток: Рамкова угода про неповну зайнятість. Графік: Положення Директиви мають бути впроваджені протягом 3 років із дати набрання чинності цією Угодою;

- Директива Ради № 98/59/СС від 20.07.1998 р. про наближення законодавств держав-членів щодо колективного звільнення. Графік: положення Директиви мають бути впроваджені протягом 4 років із дати набрання чинності цією Угодою;

- Директива Ради № 2000/43/СС від 29.06.2000 р. про реалізацію принципу рівного ставлення незалежно від расового чи етнічного походження. Графік: Положення Директиви мають бути впроваджені протягом 4 років з дати набрання чинності цією Угодою;

- Директива Ради № 2000/78/СС від 27.11.2000 р., що встановлює загальну систему рівного ставлення у сфері зайнятості та професійної

\footnotetext{
46 Угода про асоціацію між Україною, 3 однієї сторони, та Європейським Союзом, Європейським співтовариством 3 атомної енергії і їхніми державами-членами, з іншої сторони. Угоду ратифіковано із заявою Законом № 1678-VII від 16.09.2014. URL: http://zakon0.rada.gov.ua/laws/show/984_011/paran147\#n147.
} 
діяльності. Графік: Положення Директиви мають бути впроваджені протягом 4 років із дати набрання чинності цією Угодою. Директива Ради № 2004/113/СС від 13.12.2004 p. про реалізацію принципів рівного ставлення до чоловіків та жінок у питаннях доступу та постачання товарів та послуг. Графік: положення Директиви мають бути впроваджені протягом 3 років із дати набрання чинності цією Угодою;

- Директива Ради № 96/34/СС від 03.06.1996 р. про рамкову угоду щодо батьківської відпустки, укладену СКПРС [Спілка конфедерацій підприємців i роботодавців Європи], ЄЦРП [Свропейський центр роботодавців i підприємств] та ЄКПС [Свропейська конфедерація профспілок]. Графік: Положення Директиви мають бути впроваджені протягом 3 років із дати набрання чинності цією Угодою ${ }^{47}$.

Варто констатувати, що стан впровадження положень вищезазначених нормативно-правових актів $є$ незадовільним. Так, досі не було прийнято ні Трудовий кодекс України, ні новий закон про службу в органах місцевого самоврядування. У цьому контексті показовим прикладом був законопроєкт про внесення змін до Закону України «Про службу в органах місцевого самоврядування〉 № 8369 від 17.05.2018 р., яким передбачалося оновлення правових передумов для врегулювання статусу службовців місцевого самоврядування та виборних посадових осіб місцевого самоврядування, забезпечення політичної нейтральності службовців місцевого самоврядування, врегулювання законом основних питань служби в органах місцевого самоврядування та надання органам місцевого самоврядування повноважень самостійно вирішувати питання формування умов оплати праці виборних посадових осіб та службовців місцевого самоврядування, інші питання проходження служби в органах місцевого самоврядування та встановлення загальних правил та гарантій для здійснення таких повноважень, адаптації основ служби в органах місцевого самоврядування до концептуальних підходів, закладених Законом України «Про державну службу» ${ }^{48}$. Разом із тим нині відповідний законопроєкт відкликано і знято з розгляду.

\section{ВИСНОВКИ}

Правове регулювання праці посадових осіб органів місцевого самоврядування в ЄС здійснюється на двох рівнях: наднаціональному (зокрема, в межах діяльності Ради Свропи) та національному (в межах конкретних країн).

\footnotetext{
47 Додаток XL до глави 21 «Співробітництво у галузі зайнятості, соціальної політики та рівних можливостей» розділу V «Економічне і галузеве співробітництво». URL: http://vobu.com.ua/app/webroot/img/custom/ editor/euro/ugoda/asd44.pdf.

48 Проєкт Закону про внесення змін до Закону України «Про службу в органах місцевого самоврядування» № 8369 від 17.05.2018 p. URL: http://w1.c1.rada.gov.ua/pls/zweb2/webproc4_1?pf3511=64016.
} 
Базові засади правової регламентації встановлені в таких нормативноправових актах, як Європейська хартія місцевого самоврядування, Гельсінська декларація регіонального самоврядування, та окремих рекомендаціях Ради Європи. Положення цих правових документів стосуються здебільшого необхідності забезпечення муніципальним службовцям правового статусу, подібного до правового статусу державних службовців, а також встановлення муніципальним службовцям належних можливостей для навчання, оплати праці та кар'єрного росту.

На національному рівні законодавство країн СС у частині регулювання праці посадових осіб органів місцевого самоврядування характеризується такими рисами:

1) відсутність терміна «посадова особа органу місцевого самоврядування» та використання терміна «муніципальний службовець» та «публічний службовець», а в окремих країнах - оперування поняттям «місцева державна служба»;

2) поділ посад на постійні (чиновницькі) та непостійні (виборні);

3) високий рівень соціального захисту муніципальних службовців (пенсійного забезпечення, трудових прав, гарантій діяльності тощо);

4) тенденція до забезпечення гендерної рівності чоловіків і жінок шляхом закріплення в законодавстві квоти для жінок (на рівні скандинавських країн);

5) високий рівень престижності муніципальної служби (зокрема, німецьке законодавство оперує поняттям «почесні обов'язки» та «почесна служба»);

6) розвинутість інституту політичної відповідальності виборних муніципальних посад та суворість законодавства про дисциплінарні проступки муніципальних службовців (французька модель);

7) нормативно закріплений кодекс поведінки публічних службовців, їхніх прав та обов'язків;

8) наявність суворих вимог щодо несумісності та детально врегульованого інституту конфлікту інтересів в муніципальній службі.

Основні напрями впровадження в Україні досвіду правового регулювання інституту праці посадових осіб органів місцевого самоврядування в країнах ЄC, на нашу думку, мають полягати в наведеному нижче:

1) кодифікація законодавства про муніципальну службу на рівні окремого законодавчого акта, який би охоплював також питання соціального та пенсійного забезпечення муніципальних службовців (як це зроблено у Франції та Польщі). Такий варіант дасть змогу уникнути зайвих колізій у правовому регулюванні не тільки праці, але й загалом правового статусу муніципальних службовців;

2) оновлення кодексу поведінки публічних службовців, їхніх прав та обов’язків (у частині «цифрової» етики - за моделлю Франції або Німеччини); 
3) французьке законодавство про муніципальну службу гарантує чиновникам свободу думки (свободу вираження поглядів), що варто закріпити і на рівні національного законодавства України;

4) необхідним є впровадження послідовної гендерної політики (як це зроблено в Фінляндії) з метою усунення нерівності в доступі до муніципальної служби чоловіків та жінок;

5) створення та ведення реєстру інтересів посадових осіб органів місцевого самоврядування з метою уникнення наявності конфлікту інтересів під час перебування на муніципальній службі (досвід Великобританіі);

6) встановлення прозорості та публічності проведення конкурсу на обійняття вакантних посад за польською моделлю, а також провадження інституту підготовчої служби;

7) встановлення конкретних та чітких вимог щодо проведення періодичної оцінки (атестації) працівників не менше двох разів на рік;

8) узгодження чинного законодавства 3 вимогами Угоди про асоціацію. Основним позитивом від такої адаптації законодавства буде: 1) узгодження чинних стандартів праці посадових осіб органів місцевого самоврядування 3 європейськими вимогами та 2) отримання Україною змоги стати повноправним членом ЄС у найближчому майбутньому.

\section{АНОТАЦІЯ}

У статті аналізується досвід країн Європейського Союзу в частині правового регулювання праці посадових осіб органів місцевого самоврядування, а також обгрунтовуються пропозиції щодо вдосконалення українського законодавства у цій сфері 3 урахуванням європейського досвіду.

Автор аналізує наднаціональне європейське законодавство, а саме Європейську хартію місцевого самоврядування, Гельсінську декларацію регіонального самоврядування та окремі рекомендації Ради Європи, внаслідок чого доходить висновку, що цими документами закріплено загальні прагнення держав-членів Ради Свропи забезпечити гідні умови праці муніципальним службовцям - не гірші, ніж ті, що передбачені для державних службовців.

У межах дослідження автором проаналізовано досвід Німеччини, Великобританії, Франції, Польщі та Фінляндії. Автор зазначає високий рівень соціального захисту муніципальних службовців, тенденцію до забезпечення гендерної рівності чоловіків і жінок шляхом закріплення в законодавстві квоти для жінок, високий рівень престижності муніципальної служби та розвинутість інституту політичної відповідальності виборних муніципальних посад. 
Автор підтримує ідею впровадження в Україні реєстру інтересів посадових осіб органів місцевого самоврядування за британською моделлю, а також встановлення прозорості та публічності проведення конкурсу на обійняття вакантних посад за польською моделлю. Автор акцентує на необхідності встановити конкретні та чіткі вимоги щодо проведення періодичної оцінки (атестації) працівників не менше двох разів на рік.

У межах статті аналізується подальший вектор дій щодо імплементації окремих положень Угоди про асоціацію (а саме частини про співробітництво в галузі зайнятості, соціальної політики та рівних можливостей), а також констатовано низький ступінь гармонізації українського законодавства до стандартів ЄС.

\section{ЛIТЕРАТУРА}

1. Астапова Т.О. Адаптація зарубіжного досвіду реформування діяльності органів місцевого самоврядування в Україні : автореф. дис. ... канд. наук з держ. упр. : 25.00 .04 / Нац. акад. держ. упр. при Президентові України, Харк. регіон. ін-т держ. упр. Х., 2010. 20 с.

2. Вольман Х. Сравнительный анализ систем местного самоуправления в Германии и в европейских странах. Мунищипальная власть. 2015. № 1-2. С. $63-71$.

3. Гельсінська декларація регіонального самоврядування, прийнята на Конференції міністрів держав - членів Ради Європи, відповідальних за місцеве та регіональне врядування 28 червня 2002 року. URL: https://rm.coe.int/16805e1fde.

4. Додаток XL до глави 21 «Співробітництво у галузі зайнятості, соціальної політики та рівних можливостей» розділу $\mathrm{V}$ «Економічне i галузеве співробітництво». URL: http://vobu.com.ua/app/webroot/img/custom/ editor/euro/ugoda/asd44.pdf.

5. Досвід децентралізації у країнах Свропи : збірник док. пер. $з$ іноз. мов / Заг. ред. В.Б. Гройсмана. Київ : Інститут законодавства Верховної Ради України, 2015. 735 с.

6. Евдокимов В.Б., Старцев Я.Ю. Местные органы власти зарубежных стран: правовые аспекты. Москва : Спарк, 2001. 661 с.

7. Європейська соціальна хартія від 03.05.1996 р., ратифікована Україною згідно із законом від 14.09.2006 р. № 137-V. URL: http://zakon2.rada.gov.ua/ laws/show/994_062.

8. Красівський О.Я. Еволюція системи місцевого самоврядування у Німеччині (на прикладі землі Бранденбург): історико-управлінський аспект / О.Я. Красівський, М.М. Янишевський. Аспекти публічного управління. 2016. № 6/7 (32/33). С. 82-91. 
9. Костюк В.Л., Мозолевський П.В. Право на службу в органах місцевого самоврядування: сутність, проблеми, тенденції законодавчого забезпечення. Журнал східноєвропейського права. 2017. № 41. C. 4-12. URL: http://easternlaw.com.ua/wp-content/uploads/2017/07/kostiuk_ mozolevskyi_41.pdf.

10. Лапшина И.Е. Местное управление и территориальная организация публичной власти в Великобритании. Правовая политика и правовая жизнь. 2012. № 2. C. 141-150.

11. Лапшина И.Е. Формы взаимодействия центральных и местных органов управления Великобритании. Государство и право. 2013. № 5. C. $76-81$.

12. Люхтерхандт Г. Местное самоуправление в новых землях Германии. Берлин, 2012 г. 312 с.

13. Миронов Н. Местное самоуправление во Франции. Муниципальная власть. 2014. № 2. С. 45-49.

14. Місцеве самоврядування в країнах Скандинавії та Балтії. URL: http://old.decentralization.gov.ua/pics/attachments/Misceve-samovryaduvannyav-krayinah-Skandiinaviyi-ta-Baltiyi.pdf.

15. Муниципальное право зарубежных стран (сравнительно-правовой анализ) : Учебное пособие для вузов / под ред. д.ю.н., профессора В.В. Еремяна. Москва : Академический проект; Фонд «Мир». 2005. 344 с.

16. План заходів 3 реалізації нового етапу реформування місцевого самоврядування та територіальної організації влади в Україні на 20192021 роки : Розпорядження Кабінету Міністрів України від 23 січня 2019 р. № 77-p. URL: https://zakon.rada.gov.ua/laws/show/77-2019-\%D1\%80?lang=en.

17. Проєкт Закону про внесення змін до Закону України «Про службу в органах місцевого самоврядування» № 8369 від 17.05.2018 p. URL: http://w1.c1.rada.gov.ua/pls/zweb2/webproc4_1?pf3511=64016.

18. Прудиус Л. Розробка стандартів підвищення кваліфікації публічних службовців в умовах європейської інтеграції України: правові засади. Национальньй юридический журнал: теория и практика. Київ, 2016. C. 122-131. URL: http://www.jurnaluljuridic.in.ua/archive/2016/3/9.pdf.

19. Рекомендація Комітету Міністрів Ради Європи REC(2007)12 про розвиток потенціалу на місцевому та регіональному рівні, прийнята 10 жовтня 2007 року. URL: https://www.coe.int/en/web/freedom-expression/ committee-of-ministers-adopted-texts/-/asset_publisher/aDXmrol0vvsU/content/ recommendation-cm-rec-2007-2-of-the-committee-of-ministers-to-memberstates-on-media-pluralism-and-diversity-of-media-content?_101_INSTANCE_ aDXmrol0vvsU_viewMode=view/. 
20. Рекомендація Комітету Міністрів Ради Європи REC(2001)19 про участь громадян у місцевому суспільному житті, прийнята 6 грудня 2001 року. URL: https:/www.coe.int/en/web/good-governance/newsroom/ -/asset_publisher/HvcSRSRYLNU4/content/participation-of-citizens-in-localpublic-life-revision-of-recommendation-cm-rec-2001-19-of-the-committee-ofministers?inheritRedirect $=$ false.

21. Угода про асоціацію між Україною, 3 однієї сторони, та Європейським Союзом, Свропейським співтовариством з атомної енергії і їхніми державами-членами, 3 іншої сторони. Угоду ратифіковано із заявою Законом № 1678-VII від 16.09.2014. URL: http://zakon0.rada.gov.ua/laws/ show/984_011/paran147\#n147.

22. Янгол Н.Г., Болотина Е.В. Правовой статус муниципальных служащих во Франции. Вестник Санкт-Петербургского университета МВД России. 2016. № 1. URL: https://cyberleninka.ru/article/n/pravovoy-statusmunitsipalnyh-sluzhaschih-vo-frantsii.

23. Ustawa $\mathrm{z}$ dnia 21 listopada 2008 r. o pracownikach samorządowych. URL: https://isap.sejm.gov.pl/isap.nsf/DocDetails.xsp?id=WDU20082231458.

\section{Information about authors: Melnyk P. V., $3^{\text {rd }}$ year PhD Student} Ioannikii Malinovskyi Institute of Law of the National University of "Ostroh Academy" 2, Seminarska str., Ostroh, Rivne region, 35800, Ukraine

Melnyk V. P., Doctor of Juridical Sciences, Associate Professor at the Department of Criminal Law, Procedure and Criminology Kyiv Institute of Intellectual Property and Law of the National University "Odesa Academy of Law" 210, Kharkivske Shosse str., Kyiv, 02121, Ukraine 